\title{
Critical Analysis of Advertising: Enhancing Identity Construction in EFL Classrooms ${ }^{1}$
}

\section{Análisis Crítico de la Publicidad: Fortaleciendo la Construcción de Identidad en Clases de Inglés como Lengua Extranjera}

\author{
Mónica Yohanna Lara Páez ${ }^{2}$ \\ Colegio Cooperativo Reyes Patria - Sogamoso \\ monitayw@hotmail.com
}

Received: November 17, 2016

Accepted: December 12, 2016

How to cite this article (APA, 6th ed.): Lara-Páez, M. (2017) Critical Analysis of Advertising: Enhancing Identity Construction in EFL Classrooms. Enletawa Journal, 10 (1), $27-42$

\begin{abstract}
Critical media literacy is a competence that promotes the analysis of messages and strategies used by mass media through the enhancement and implementation of critical skills. This research report describes what a process of critical analysis of advertisements revealed about a group of twenty-one tenth graders' identity construction at a private institution in Duitama (Boyacá - Colombia). The implementation of eight task- based workshops led them to reflect about the role of advertising in their contexts and its relationship with their identity construction process. As a result, the tasks developed during the workshops guided students in understanding the role advertising plays in their daily life.

1 Research Report

2 Mónica Yohanna Lara Páez is Modern Languages Teacher graduated from Universidad Pedagógica y Tecnológica de Colombia. Currently, she is pursuing an M.A. degree in Language Teaching at the same university. Nowadays, she works as an English teacher at Colegio Cooperativo Reyes Patria in Sogamoso. Her research interests mainly focus on autonomy and critical skills.
\end{abstract}


Key Words: Advertising, Critical Media Literacy, Critical Thinking, Identity Construction.

\section{Resumen}

La literacidad crítica de medios es una competencia que promueve el análisis de los mensajes y estrategias utilizados por los medios de comunicación a través de la mejora e implementación de habilidades críticas. De esta manera, este reporte de investigación describe lo que un proceso de análisis crítico de anuncios publicitarios reveló acerca del proceso de construcción de identidad de veintiún estudiantes de grado décimo, en una institución privada localizada en Duitama (Boyacá - Colombia). La implementación de ocho talleres basados en tareas guió a los estudiantes hacia la reflexión sobre el rol de la publicidad en su contexto y cómo esta se relaciona con su proceso de construcción de identidad. Como resultado, las actividades desarrolladas durante los talleres ayudaron a los estudiantes a comprender el rol de la publicidad en su vida diaria.

Palabras Clave: Literacidad crítica de medios, habilidades críticas, anuncios publicitarios, construcción de identidad. 


\section{Introduction}

Nowadays, mass media has a great impact in society since technological advancements allow media to approach people in a more effective and constant way. People are not aware of the messages they receive through sounds and images in advertisements (Alcantud, 2011). Based on this situation, people are exposed to huge amounts of information every single day. However, most of them are not conscious of this fact because mass media has become a normal phenomenon. Taking into account that advertising is a very common media tool, it is necessary to identify its function and impact on society through a process of critical analysis of advertising.

In terms of the study reported in this article, an aspect that caught my attention was the fact that most tenth graders at the Instituto Gestión Informático Guía Académica (GIGA) demonstrated decision making and behaviors based on what they perceived from advertising. A concerning observation was not the level of exposure these students had to advertising, but rather their lack of awareness on how mass media was influencing their identity construction process. According to Aguirre (2004), teenagers are exposed to different kinds of information, either positive or negative, so they need to have the skills and competence to appropriately make use of this information.

I conducted this study during an EFL class. A relevant aspect resulting from this study was an improvement of the students' English level. There were significant lan- guage gains in terms of vocabulary and grammar, but mainly in writing.

\section{Problem Statement}

Some teenagers shape their personalities and thoughts by imitating or copying the information they see from mass media. Nowadays, young people are constantly exposed to media as a means of constructing their own identity. Media constantly modifies the values and beliefs in which people build their decision making and define themselves (Burleson, 2010). This statement affirms that mass media highly influences teenagers' identity because it uses different strategies to attract people on a daily basis. In this sense, the relationship between mass media and identity construction is highly evident in different sociocultural aspects, as claimed in the following statement:

One of the prevailing themes in mass media is how we define ourselves. Identity is influenced by multiple factors such as class, gender, race and ethnicity. The ramifications of these categories on identity individually and collectively emphasize the complexity of how the media constructs identity through images and national representations, and how these representations in turn affect individual subjectivity (Dave, 2002, p. 247).

In view of this, the influence media has on identity construction can be identified through the way people shape their identity based on the information they provide. Most of the information humans receive has a purpose which can influence their behaviors, ideologies and 
perceptions of the world. This is done through the use of different tactics to call their attention and persuade them to act or think in a certain way. Bearing in mind the images and persuasive vocabulary that advertising uses as strategies to influence people's behavior and decision making, it can be considered one of the most manipulating media tools.

According to the previous information and some observations done during the English classes, the impact of advertising is evident as a consequence of easy access to media tools and the way televisions, magazines and the internet shape teenagers' mindsets. The problem identified was not the level of exposure that students had to advertising, but rather that they did not know the appropriate strategies available to analyze and interpret beyond what they saw and heard. Therefore, their identity was highly influenced by advertising. Therefore, it is necessary to highlight the fact that viewers are not always consciously aware of the messages targeted by advertisements (Alcantud, 2011).

Based on the observations of the dynamics of twenty-one tenth graders from GIGA, done by the researcher during the two-hour English and Spanish classes for three weeks, most of students displayed an influence on their behavior and personality caused by advertising. Some of the aspects that portrayed this situation were the importance students placed on the way they looked and the great number of branded products they used. Moreover, the way they expressed and related to their partners also evidenced the ideologies of popularity and beauty promoted by advertising. Because of the impact advertising had on these students, they were selected as the focus of this research study.

In terms of their identity construction, most students affirmed that they did not think that advertising influenced this process. This is because they believed that they could decide what they liked and what they did not and behave accordingly. Besides the influence of advertising on students' identity, this media tool also promoted problems, such as bullying, discrimination, alcoholism, and low self-esteem within this population. Consequently, students thought that people using branded products were wealthy and called them Gomelos, which is an expression used to refer to rich people who own expensive clothes and objects. It is also used to describe people as rich boys or girls who indulge and have everything they want. Additionally, students who did not have the same opportunities to purchase branded items or act a certain way were discriminated. Students also said that advertising made them want to have all the products advertised, even when they did not need them.

\section{Theoretical Framework}

\section{Identity}

Bearing in mind the fact that identity is one of the main constructs of this research study, some theories will be presented as a means of providing a better understanding of the purpose of this project. According to Fearon (1999, p. $10)$, “identity is one's feelings about one's 
self, character, goals, and origins." Based on Fearon, it can be stated that identity is very important for every human being. It portrays different aspects on what we really are and how we identify ourselves as individuals.

Another relevant fact of identity is that it changes throughout time. Once again, Fearon (1999, p. 15) established that 'identities' are changeable and historically contingent, which contradicts an older theory in which identities were thought to remain the same. According to this idea, identity is variable and inconstant. It is highly influenced by the environment in which it is constructed, and it is determined by the ideologies and premises of the social context in which it belongs.

According to the previous ideas, identity as a social construction must be taken into account. In order to support this statement, Fearon (1999, p. 14) confirmed that "identity varies over time, historically, and are the products of human thinking, discourse, and action." Thus, identity construction is a process that takes places in social contexts and is shaped according to different perspectives, relations, information and thoughts that people are exposed to in their daily life.

It is necessary for people to be aware of the importance of understanding themselves in order to construct a strong identity. Taking into account the fact that identity is influenced by our daily social experiences, it is relevant to have a foundation as part of our identity construction process, and make us proud of our roots, traditions and the aspects that configure us.

\section{Advertising}

Nowadays, advertising plays a role as a tool used by the mass media to persuade people. Durán (as cited in Alcantud, 2011, p. 2), stated that advertising is a tool that provides information and manipulates people to behave and think in a specific way. Then, it can be inferred that advertising influences people's decision making and actions. As stated during the problem stage of this project, what really concerned the researcher was not the level of exposure to mass media, but the lack of people's consciousness regarding the implicit messages that advertising sought to transmit.

To support the previous ideas, it can be said that the tools used by advertising to promote its ideologies and messages are the foundations of their success. Kilbourne (as cited in Alcantud, 2011) said:

Taken to an extreme, advertising encourages us not only to objectify each other but also to feel that our most significant relationships are with the products that we buy. It turns lovers into things and things into lovers and encourages us to feel passion for our products rather than our partners. (p.27)

Nowadays, people assess everything and everyone based on material possessions. For this reason, most people like others not because of their personality, but because of their appearance or what they wear or have. Therefore, it can be stated that advertising not only influences people's decision-making, but it also 
influences people's feelings and conceptions of the world by promoting materialistic models and imagined necessities from a consumerist perspective.

In terms of this study, advertising was approached as a media tool that persuades people's thinking and behaviors. In the words of Frolova (2014), advertising establishes a way of life that influences people's thinking and attitudes towards their own and the world. Because of this, students must understand the concept of advertising and its role in their identity construction as it influences important decisions related to their appearance, beliefs, and perceptions of the world.

\section{Critical Media Literacy (CML)}

Firstly, according to the National Association for Media Literacy Education -NAMLE (2007, p. 1) “The purpose of media literacy education is to help individuals of all ages to develop the habits of inquiry and skills of expression that they need to be critical thinkers, effective communicators and active citizens in today's world." Based on this previous statement and acknowledging that information is everywhere nowadays, younger generations must be prepared to analyze and evaluate information from a critical perspective. Thus, CML enhances people's critical thinking skills through the analysis of messages and strategies used to persuade them in advertising. In this sense, CML allows people to identify and understand the role of different components of advertising, such as: the target population, the ideas of reality provided by the images, the type and size of the letters, the use of colors, and the direct and hidden messages. CML helps people recognize the purpose of the advertisement and the way in which it may impact or not their way of thinking and behaving.

According to Gainer (2010, p. 368), "Schools are places where students can learn to transform society. In classrooms that embrace pedagogy of critical media literacy, space should be made for students to analyze and critique dominant narratives." Based on this idea, it is important to realize the role that educational settings play regarding the enhancement of skills that allow students to make informed decisions and be active agents in their society. In this way, students will have the ability to be critical thinkers and agents of change in terms of the information they receive.

In this world where mass media bombards people with messages and persuasion strategies, the strengthening of competences such as critical media literacy is a necessity. Based on the NAMLE (2007), media literacy consists of a series of communication competencies, including the ability to access, analyze, evaluate, and communicate information in a variety of ways. This includes print and non-print messages. Therefore, schools and teachers in general must start developing these competences within their classes in order to help students face different kinds of messages. In this way, students can become less vulnerable to mass media. 


\section{Critical Thinking}

For this research study, critical thinking is considered as the mental discipline that allows people to evaluate and judge arguments to foster their beliefs and actions (Huitt, 1998). The process of critical thinking is evidenced through the ability someone may have to question and analyze different ideas in order to make decisions about the situations they face in their daily life.

According to Aguirre (2004, p. 10), "Thinking well can be considered to be that type of thinking which is purposeful and reflective, and that can lead the person to consider multiple perspectives of the same issue." Consequently, critical thinking can be useful for people to create a stance on the situations and problems they go through every day. Moreover, this process allows people to analyze different arguments and ideas to acquire their own view of any situation and face it in the most appropriate way.

Similarly, Paul and Elder (2006, p. 4) point out that "Critical thinking is the art of analyzing and evaluating thinking with a view to improving it." Thus, teachers and students should understand that the process of critical thinking implies more than making simple choices in daily life. Knowing and understanding the main skills critical thinkers possess is necessary to become aware of what this process involves. Facione $(2015$, p. 5) stated "as to the cognitive skills here is what the experts include as being at the very core of critical thinking: interpretation, analysis, evaluation, inference, explanation, and self-regulation." Consequently, there should be great commitment and responsibility on behalf of people to try to strengthen these skills. This is done as a means of becoming better thinkers, since they have to constantly process reflection and analysis of their thinking, and its implications for the decisions they make every day.

\section{Pedagogical Intervention}

As previously stated, the present study was based on the development of eight task-based workshops, as a strategy to identify some aspects regarding tenth graders' identity construction through a process of critical analysis of advertisements. Based on Richards and Farrell (2005, p. 23), "a workshop is an intensive short-term activity that is designed to provide an opportunity to acquire specific knowledge and skills." This strategy was adopted in order to provide students with different tasks, allowing them to enhance their critical skills and better understand the way in which advertisements influence their identity construction process.

In order to allow students to realize the influence that advertisements had in their immediate sociocultural context, as well as motivate them to adopt CML as a way to face advertising in their daily life, each workshop had a specific goal. Altogether, the workshops had a common target. The first three workshops were designed to introduce different aspects regarding advertising, such as students' perceptions and opinions about this media tool, main means of exposure, the role and impact of advertising in society, the strategies of persuasion in advertising and the 
way it may influence the students' lives. After the presentation of the previous aspects was conducted, workshops 4, 5 and 6 aimed at making students realize the connection between advertising and identity construction. Also, these workshops introduced CML as a strategy to analyze advertising. Thirdly, since students had already realized the concept and implications of advertising and its relationship with social problems and people's identity, the last two workshops aimed at presenting CML as a strategy to analyze advertising from a critical perspective by means of reducing its impact in the students' lives and identity construction.

Finally, it is important to note that these workshops were based on the TaskBased Approach. According to Nunan (2004), this approach is known for its three stages: pre-task, task, and posttask, which provide researchers with a cycle. First, the task is introduced, then, the main task is applied. Finally, the task is reinforced in the "post-task" stage. These tasks were designed to introduce the concept of advertising from different perspectives, which required that all of them were interconnected. Consequently, the student-participants of this study developed different tasks that allowed them to understand the concepts of CML and advertising, as well as how they were related. Moreover, the implementation of different tasks improved students' English writing skills since most of the tasks asked students to express themselves in written form.

\section{Research Design}

\section{Research approach and type}

On the one hand, this project was seen from a qualitative perspective since the teacher-researcher was immersed in the specific context where this study was applied. In this sense, the researcher in-terpreted the problem related to the influence of advertising on students' identity construction, which was observed through the process of critical analysis of advertisements. Thereupon, the researcher observed the population, shared with the people involved in the process, and provided a description of the real problem based on what the population expressed. Finally, taking into account that qualitative research is concerned with subjective opinions, feelings, and experiences of individuals (Dörnyei, 2007), participants' opinions and background were very important for this project.

On the other hand, considering that the study aims to improve the situation by reducing the impact of advertising on tenth graders' identity construction, the type of research conducted was action research. In the words of Richards and Farrell (2005, p. 171), "Action research takes place in the teacher's classroom and involves a cycle of activities centering or identifying an issue, collecting infor-mation about it, devising a strategy to address it, trying out the strategy, and observing its effects." According to the previous information, this process allowed the teacher-researcher to be part of the context of the study, as well as the selected population to have a participatory role. Consequently, these agents imple- 
mented CML as a strategy that could possibly reduce the influence of advertising on the students' daily life by taking action on the setting and observing the results.

\section{Setting}

The context where this project took place was the private institute Gestión Informática Guía Académica (GIGA), located in Duitama (Boyacá). This institute was a space where there were students from different social strata, mainly 1, 2, and 3 . This setting was selected as the scenario for the development of this research proposal since the observation done by the researcher evidenced that students showed weaknesses regarding critical skills and their English language level.

\section{Population}

The population selected for this study was composed by twenty-one tenth graders from a private institute in Duitama, who were the sample population for the development of this study. This group was comprised by ten female and eleven male students, with an average age of 17 . This population was highly influenced by the messages provided by advertisements. As they stated in the survey, they were exposed to advertising most of the time. With the purpose of respecting the privacy of the participants, each one of them selected a pseudonym for this research process.

\section{Data Collection Instruments}

Field Notes. Field notes were chosen as one of the data collection methods for this study. The role of this instrument was transcendental during the implementation of the workshops to take detailed notes about the classroom dynamics. This method allowed the researcher to identify the students' most meaningful reactions towards the different tasks. At the same time, the researcher analyzed their perceptions and positions towards advertising and critical media analysis from the beginning to the end of the process.

Taking into account that data collectors must develop significant descriptions emerging from the notes they take, they transformed them into narratives from what they observed (Mack, Woodsong, McQueen, Guest and Namey, 2011). Accordingly, the field notes taken during this research include the implementation of workshops through detailed descriptions, the exemplification of the dynamics observed, and the data collected from the activities developed.

In-Depth Interview. Another valuable data collection method was an in-depth interview. According to Boyce and Neale (2006, p. 3), "In-depth interviewing is a qualitative research technique that involves conducting intensive individual interviews with a small number of respondents to explore their perspectives on a particular idea, program, or situation." According to the previous concept, twelve students were chosen at random to be interviewed. This data collection method searched for specific information, and each interview lasted at least one hour. For this reason, only twelve students were interviewed. This instrument was applied 
before and after the implementation of the workshops by means of identifying students' perceptions on advertising, the way it had influenced their identity construction, the perception they had about CML as an impact reduction strategy, and how they felt in terms of the English writing process.

Students' Artifacts. The third data collection method was students' artifacts. These instruments arose from the development of eight workshops based on the critical analysis of advertising. James (2014, p.70) stated, "students' work may be collected as time passes by and it may be used to show students' growth regarding the process they follow; however, it is hard to interpret from an accurate perspective." Given this view, students' artifacts were valuable for this study since these instruments reflected students' learning and evolution. The artifacts demonstrated their understanding about the role of advertising in their daily life based on the tasks they developed during the workshops implementation, which lasted about three months.

\section{Data Analysis}

The method selected to analyze the data collected during the implementation of the workshops was color coding. According to Böhm (2004, p. 270), "coding may be described as the deciphering or interpretation of data and includes the naming of concepts and also explaining and discussing them in more detail." In that sense, I started to read and organize the data to identify the information I had obtained during this study. Then, data were codified with different colors representing the commonalities between the information gathered from each one of the instruments. Later, I related that information with the specific aspects of the study. This process of data analysis allowed me to establish the categories and sub-categories that answered the main question of this study (Figure 1).

\section{Categories and Sub-categories}

The following chart presents the different categories and sub-categories resulting from the data analysis. (Figure 1)

\section{Open Your Eyes, Look Within}

The name of this category emerged from the idea that critical analysis of advertising is a way to help people open their eyes to its influence and look within to accept themselves and foster their identity construction.

At the beginning of this process, students were not aware of the influence advertising had on their daily life. Beyond being aware of that influence, students realized that although advertising cannot be avoided, they could reduce its impact on their identity construction through the implementation of strategies, such as CML. Based on that, this category corresponds to the main research question, which is related to the influence of a process of critical analysis of advertising in the tenth graders' identity construction. This category answered the research through the three following subcategories: 


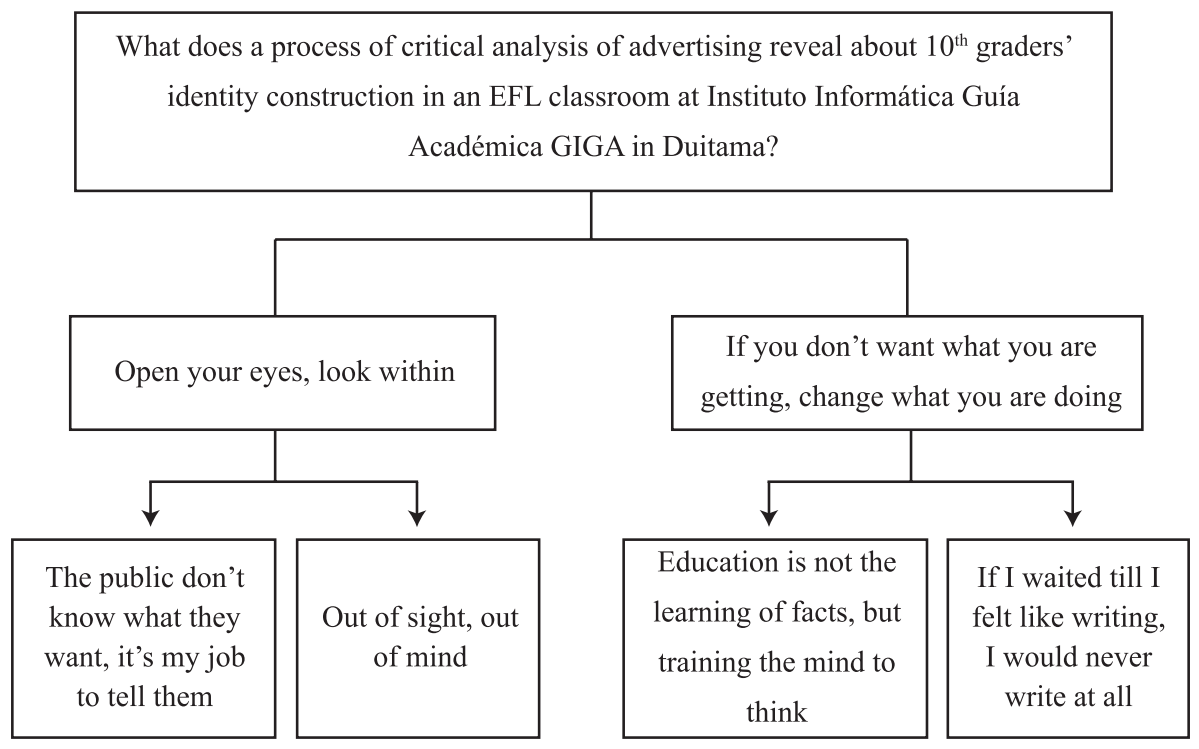

Figure 1. Summary of Categories and Sub-categories

"The public don't know what they want; it is my job to tell them" Alec Issigonis (n.d.). This first sub-category emerged from the first category during the data analysis process. I decided to give it this title because it represents what this study aimed to show, which was the influence of advertising on people's identity when they could not critically make decisions on their own.

According to the students' ideas and concepts on advertising, I realized that they were not aware of the impact that advertising had on their daily life. They were just perceiving advertising as a strategy to sell a product. Based on Kenechukwu, Asemah and Edegoh (2013, p. 952), "the goal of advertising is not just to sell products and services, but also to persuade consumers to act or think in a particular way." In order to do so, most ad- vertising persuades its audience with hidden messages that people cannot perceive at first sight. This situation was observed frequently during the implementation of the first workshops. Some students were even convinced that advertising did not influence them at all.

During the implementation of the workshops, students became conscious of the real role that advertising played in their lives. Most of them realized that they were so highly affected by the messages presented, that they wanted to change the way they looked and behaved to imitate the models they saw everywhere.

Advertising has planted on my head in terms of the advertisements of perfect body and woman appearance, so I think that in that sense I felt down. Those advertising affected my emotions so I became more influenced by it. Greeny (Indepth interview, 20/08/2015). 
However, the workshops implemented allowed students to realize that critical analysis of advertising helped them to open their eyes to this media tool. They started to observe and analyze advertisements to understand which messages were influencing them. In this sense, it was seen that the development of workshops based on critical analysis of advertising changed students' perspective of this tool, as well as the impact it had in their daily decisions.

Strategies of critical media literacy help a lot to realize that advertising is not what it seems and invite us to reflect each time we watch advertising or something like that, so we can realize the hidden message and that helps a lot to reduce the credibility we have on advertising. Campana (In-depth interview, 20/08/2015)

Out of sight, out of mind. This second subcategory was based on the idea that people are not aware of the relationship between social problems and advertising, they do not reflect and take action against the negative impact it has in their context and on themselves. At the beginning of the workshop, most students had different thoughts on issues like discrimination, stereotyping, and low self-esteem, as presented in the following statements:

People do not buy branded product because they do not have the resources to do so. People who do not buy branded product represent the mere humility. (The student used the concept humility actually to refer to poverty).Valluno (Field Notes, class discussion. Workshop 3. 22 107/2015)

Fat people portrays laziness because they do not do exercise. They do not take care of themselves; they eat lots of fat products. I would not like to be fat. That's why I exercise. Campana (In-depth interview, 20/08/2015)

The strategies used by advertising to persuade people were introduced during the workshops. Students not only changed and reflect upon their perception of advertising and the influence it had in their own identity construction, but they also realized how advertising ideologies made people suffer which affected their lives.

Sometimes advertising is bad because it changes people, now a person just by watching a normal advertising is influenced in the way he/she has to be otherwise that person will be rejected, now itis the way I watch it, that you cannot let advertising dominate you because it has lots of subliminal messages. Vampire (InDepth interview, 18/08/2015).

Fitness advertising may have a great influence in a woman because she can start to exercise a lot or even she can suffer from anorexia because she does not want to look fat. Lalo (In-Depth interview, 18/08/2015).

After the development of the workshops, students understood the role advertising played, and the impact it had on their identity construction. Most of them reflected on how beauty ideals led them to adopt some behaviors that were affecting their own identity in order to become someone totally different. Moreover, they learned that they must not judge other people because of the way they look, feel, or behave; it is part of everyone's identity to be different in a certain way.

If you don't want what you are getting, change what you are doing. 
This second category emerged from the second most common topic found during the data analysis process of this study. This topic referred to the improvement of critical and language skills during the implementation of the workshops based on the critical analysis of advertising.

The strengthening of critical and language skills was very important for the development of this project given that these skills would provide students with more opportunities and a better way of life. Thus, the name of this category summarizes the idea that if people want better results from what they are doing, they must make use of their skills and apply them in their lives.

\section{"Education is not the learning of} facts, but training the mind to think" Albert Einstein (n.d.). The name of this subcategory is conceived from the idea that education goes beyond the fact of learning or memorizing information about a specific topic; it also involves strengthening our students' competences and skills to face the real world.

Bearing in mind that advertising surrounds students most of the time, it is a must for schools to foster critical skills in order to make students stronger critical thinkers on the real intention of advertising. Based on that, the implementation of work-shops on critical analysis of advertising was a way to enhance critical skills to help students diminish the impact of advertising on their daily lives.

Given that critical analysis of advertising is a process based on critical thinking, the workshops implemented during this research were designed in regard to this process. According to Stocchetti and Kukkonen (2011, p. $10)$, "Critical thinking allows you to ask questions about yourself and your response to the media, about the hidden agendas of media texts, and about your role in society and the media." Based on this previous statement, through a critical analysis of advertisements, students were able to interpret, analyze and evaluate their interaction with media. Students' demonstrated this aspect of critical thinking, as seen below:

Advertising has influenced a lot the way I dress and brush, everything because I did not care about that before, but as I was growing up advertising changed me that I had to dress this way, and brush myself this way, it influenced me a lot. Lalo (In-depth interview, 18/08/2015)

As previously shown, students were able to reflect on advertising and evaluate it from a critical perspective. They established that advertising is not always bad; they also said that it is up to them to stop being dominated by the media. Based on the process they followed, students realized how important it was for them to start analyzing advertising in order to prevent them and others from being influenced by this media tool. At the end, these were some of their conclusions regarding advertising and identity construction:

Through critical analysis of advertising I became more critical. I think this is something that must be implemented in all the classes because there are people who said "hey look this is new we have to buy it"; so this process changes 
us and may help those people to diminish that. Lalo (Field Notes, class discussion. Workshop 8. $09 / 08 / 2015)$

Finally, as shown above, students learned to analyze and reflect about the messages and ideologies promoted by advertising. Thus, these results prove that students became aware of the way advertising impacted their attitudes and behavior, and they established a connection between this media tool and their own identity.

"If I waited till I felt like writing, I would never write at all." The name of this subcategory emerged from the idea that students must be encouraged to write in English. Otherwise they will not foster this skill in its entirety. According to Rojas (2005), as quoted by Hurtado (2010, p.22), "The key to an effective school writing program is a teacher who knows how to use, to find, and to create situations and contexts in which pupils feel engaged in writing and grow in their skill". Based on this, the different activities developed through the workshops on the critical analysis of advertising aimed at fostering students' writing skill. This was done through the development of simple written exercises that improved students' writing skill and grammar construction progressively.

The workshops were appropriate to improve English writing as well as pronunciation, all of that was fundamental because the way in which they were design allowed us to work on writing and what we do was easy. Greeny (In-depth interview, 20/08/2015).
Draw from the workshops implementation I feel more comfortable in English. At the beginning for example I did not feel prepared to write in English. Now I feel much better and I have noticed the difference because I had a very basic English level. Greeny (In-depth interview, 20/08/2015)

Finally, it was evident that the activities developed during the workshops on critical analysis of advertising fostered students' writing skill. Of course, due to time constraints, students did not become perfect writers, but more importantly they lost the fear to write in English. They became immersed in a process that lets them express their perceptions on identity and advertising by writing in English.

\section{Conclusions}

Although the study was carried out as expected, there were a couple of limitations that had to be taken into account. On the first hand, the fact that the workshops were developed in English was a great impediment for students when they wanted to express everything they wanted to say about identity and advertising. As students did not feel comfortable at first when expressing themselves in English, it was a difficult at the beginning when the workshops were first implemented. Then, as they gained confidence in writing, a new problem arose because they wanted to say lots of interesting things though they were still learning how to write.

Another relevant aspect for the final results of this research was the reliability of the interventions done by the participants, taking into account that this process 
was based on their own perceptions and experiences regarding the role advertising had in their lives. I had to implement some techniques, such as in-depth interviews, which allowed me to discover specific details about students' perceptions and the way advertising had shaped their identity through their thoughts.

Taking into account that the main objective of this study was based on describing what a process of critical analysis of advertising revealed about $10^{\text {th }}$ graders identity construction, students changed their perspective on advertising. They became more critical towards the messages and ideologies imposed by this media tool, which in turn strengthened their identity construction. Through their participation in the development of the workshops, students understood the concept of advertising and the impact it had in their daily lives.

In terms of writing, students saw these workshops as an opportunity to strengthen this skill. Besides the fact that at the beginning they felt uncomfortable with the idea of writing in English, as the workshops advanced, they felt more confident writing. As a result, they were able to write short reflections and opinions about the relationship between advertising and identity. Given that most of them had never written in English before the implementation of the workshops, this show great progress made.

\section{References}

Aguirre, I. (2004). Exploring the critical thinking skills of analysis and evalua- tion in $9^{\text {th }}$ graders through the use of authentic materials. HOW, a Colombia Journal for English Teachers, 11, 9 - 23.

Alcantud, M. (2011). Manipulation of teenagers through advertising: a critical discourse approach. Revista de Lingüística y Lenguas Aplicadas. 20 - 37.

Böhm, A. (2014). Theoretical Coding: Text Analysis in Grounded Theory. A companion to Qualitative Research. London: SAGE publications

Boyce, C. and Neale, P. (2006). Conducting In-Depth Interviews: A Guide for Designing and Conducting In-Depth Interviews for Evaluation Input. Watertown, Massachusetts. USA: Path Finder International.

Burleson, M. (2010). Mass Media's Relationship with Adolescents' Values and Behaviors: A Theory of Mediated Valueflection. USA: Georgia State University.

Dave, S. (2002). Identity Formation and Difference in Mass Media. In Journalism and Mass Communication (pp. 247261). University of Wisconsin - Madison.

Dörnyei, Z. (2007). Research Methods in Applied Linguistics. New York: Oxford University Press.

Facione, P. (2015). Critical Thinking: What It Is and Why It Counts. Measured Reasons and the California Academic Press, Millbrae, CA.

Fearon, J. (1999). What is Identity (As We Now Use the Word)? Department of Political Science. Stanford University.

Frolova, S. (2014). The Role of Advertising in Promoting a Product. Centria University of Applied Sciences. 
Gainer, J. (2010). Critical Media Literacy in Middle School: Exploring the Politics of Representation. Journal of Adolescent and Adult Literacy. International Reading Association. 363 - 373.

Huitt, W. (1998). Critical thinking: An overview. Educational Psychology Interactive. Valdosta, GA: Valdosta State University. http://www.edpsycinteractive. org/topics/cogsys/critthnk.html

James, A. (2014). Qualitative Data Collection. Sage Publications. Walden University, USA.

http://www.sagepub.com/sites / default/files/upm-binaries/15565_ Chapter_4.pdf

Kenechikwu, S. A., Asemah, E., and Edegoh, L. (2013). Behind Advertising: The Language of Persuasion. International journal of Asian Social Science, 3 (4), 951-959.

Mack, N., Woodsong, C., Macqueen, K., Guest, G., and Namey, E. (2005). Qualitative Research methods: A Data Collectors' Field Guide. North Carolina, USA: Family Health International.

National Association for Media Literacy Education. (2007). Core Principles of Media Literacy Education. Retrieved From: http:/ / namle.net/publictions / core-principles/

Nunan, D. (2004). Task-Based Language Teaching. Cambridge: Cambridge University Press.

Paul, R. and Elder, L. (2006). The Miniature guide to Critical Thinking, Concepts and Tools. Foundation for Critical Thinking, $4^{\text {th }}$ edition. Retrieved from: www.criticalthinking.org
Richards, J., and Farrell, T. (2005). Professional Development for Language Teachers, Strategies for Teacher learning. New York: Cambridge University Press. 